\title{
Nyeri Punggung pada Operator Komputer Akibat Posisi dan Lama Duduk
}

\author{
Dyah Wulan Sumekar RW, Deny Natalia ${ }^{2}$ \\ ${ }^{1}$ Bagian Ilmu Kesehatan Masyarakat/Ilmu Kedokteran Komunitas \\ ${ }^{2}$ Program Studi Pendidikan Dokter \\ Universitas Lampung, Lampung
}

\begin{abstract}
Abstrak
Salah satu nyeri yang sering terjadi pada manusia adalah nyeri punggung, umumnya terjadi pada orang dewasa usia 33-55 tahun. Dari data Rumah Sakit Umum Daerah Lampung Tengah tahun 2006, tercatat 32 pasien nyeri otot dan meningkat dua tahun berikutnya. Sebagian besar penderita bekerja sebagai operator komputer. Tujuan utama penelitian ini untuk mengetahui pengaruh posisi dan lama duduk terhadap nyeri punggung. Jenis penelitian adalah cross sectional terhadap 120 operator komputer di Kecamatan Bandar Jaya Kabupaten Lampung. Hasil penelitian menunjukkan pada posisi duduk baik 27/65 (41,5\%) mengalami nyeri punggung, sedangkan pada posisi tidak baik 11/12 (91,7\%), dengan $p=0,011$ dan risiko 15,481 kali. Pada lama duduk $>4$ jam didapatkan 37/63 (58,7\%) nyeri punggung, sedangkan $<4$ jam $1 / 13(7,1 \%)$, dengan $\mathrm{p}=0,006$ dan risiko 18,497 kali. Gabungan posisi dan lama duduk berpengaruh secara bermakna terhadap nyeri punggung $(\mathrm{p}=0,017$ dan 0,010$)$ dan memberikan risiko 21,400 dan 24.607 kali. Disimpulkan posisi dan lama duduk masing-masing berpengaruh dan merupakan faktor risiko terhadap nyeri punggung. Gabungan posisi dan lama duduk meningkatkan pengaruh dan risiko. [MKB. 2010;42(3):123-7].
\end{abstract}

Kata kunci: Lama duduk, nyeri pungung, posisi duduk

\section{Computer Operator's Low Back Pain Caused By Sitting Position and Duration}

\begin{abstract}
One of the pain that often occurs in human is low back pain, usually occurs in adults aged 33-55 years. According to data at regional hospital Lampung Tengah in 2006, there were 32 patients with low back pain, and increased in the next two years. Majority of patients were computer operator. The purpose of this study was to determine the effect of sitting position and duration on low back pain. This study was cross sectional study of 120 computer operators in Bandar Jaya Disctrict of Lampung. The results showed that 27/65 (41.5\%) on good sitting position group experienced low back pain, while in the bad sitting position was11/12 (91.7\%), with $p=0.011$ and risk value 15.481 times. In $>$ the $>4$ hours sitting duration group, 37/63 (58.7\%) experienced low back pain, whereas in $<4$ hours group was $1 / 13(7.1 \%)$, with $\mathrm{p}=0.006$ and risk value 18.497 times. Combination of -sitting position and duration has a significant effect on low back pain $(p=0.017$ and 0.010$)$ and gave 21.400 and 24607 times risk. In conclusion, each sitting position and duration has influence on low back pain, and is a risk factor. Combination of sitting position and duration increase its impact and risk. [MKB. 2010;42(3):123-7].
\end{abstract}

Key words: Low back pain, seating duration, seating position

Korespondensi: Dyah Wulan Sumekar RW, SKM, M.Kes., Bagian Ilmu Kesehatan/Ilmu Kedokteran Komunitas, Program Studi Pendidikan Dokter Universitas Lampung, jalan Perum. jalan Griya Kencana Blok B 7 Rajabasa Bandar Lampung 35144, telepon (0721) 787876, mobile 08122516128,e-mail: sekr3-pskd@unila.ac.id 


\section{Pendahuluan}

Nyeri bekerja sebagai alarm tubuh, merupakan sinyal untuk berhenti melakukan sesuatu yang menyakitkan, sehingga melindungi tubuh dari keadaan berbahaya. Nyeri dapat dibedakan menurut tingkat keluhan yang dirasakan mulai derajat ringan sampai berat. Penderita nyeri ringan biasanya dapat menyesuaikan dengan keadaan alami, sedangkan nyeri berat dapat mengganggu cara hidup yang normal. ${ }^{1}$

Salah satu nyeri yang sering terjadi pada manusia adalah nyeri punggung. Sebagian besar nyeri punggung bersifat sederhana, yaitu berkaitan dengan kerja tulang, ligamen, dan otot punggung. Gejala nyeri punggung dapat bervariasi pada tiap orang, meliputi sakit dan kaku otot, kebas (mati rasa), serta kesemutan. Nyeri punggung dapat menjalar ke bagian tubuh lain, seperti bokong, tungkai, dan kaki.

Nyeri punggung umumnya terjadi pada orang dewasa usia 33-55 tahun. ${ }^{1}$ Pada tahun 2001-2002 telah dilaporkan banyak hari kerja yang hilang akibat gangguan muskuloskeletal. ${ }^{2}$ Sebagian besar gangguan ini merupakan nyeri punggung yang disebabkan atau diperburuk dengan bekerja. Orang dengan keluhan nyeri punggung, tidak masuk kerja rata-rata 19 hari dalam satu tahun. Penelitian lain menyatakan bahwa 17,3 juta orang Inggris, yaitu sekitar sepertiga populasi dewasa pernah mengalami nyeri punggung dan 1,1 juta orang dari jumlah tersebut mengalami kelumpuhan. ${ }^{3}$

Nyeri punggung tersebut dapat terjadi pada berbagai situasi kerja, tetapi risikonya lebih besar apabila duduk lama dalam posisi statis, karena akan menyebabkan kontraksi otot yang terus menerus serta pembuluh darah terjepit. Penyempitan pembuluh darah menyebabkan aliran darah terhambat dan iskemia, jaringan kekurangan oksigen dan nutrisi, sedangkan kontraksi otot yang lama akan menyebabkan penumpukan asam laktat. Kedua hal tersebut menyebabkan nyeri. ${ }^{1,4}$

Penelitian terdahulu terhadap karyawan suatu perusahaan asuransi yang menggunakan komputer, didapatkan hasil 14\% mengalami nyeri punggung, sedangkan di perusahaan biro pariwisata lebih tinggi, yaitu $32 \%$, sehingga setiap orang yang menggunakan komputer diajurkan untuk istirahat beberapa menit bila mengetik lebih dari 30 menit dan melakukan peregangan otot untuk mengurangi rasa nyeri punggung. ${ }^{6}$

Berdasarkan data dari Rumah Sakit Umum Daerah Lampung Tengah, kelompok penyakit muskuloskeletal, di antaranya nyeri punggung menduduki peringkat sepuluh besar penyakit terbanyak pada pasien rawat jalan. Selama tahun 2006 terdapat 32 pasien yang berobat dengan keluhan nyeri otot, sedangkan tahun 2007 terjadi lonjakan lebih dari tiga kali lipat. Sebagian besar dari mereka menderita artritis reumatoid dan sebagian lagi nyeri punggung. Selama Januari sampai Maret 2008 tercatat sekitar 40 pasien dengan keluhan nyeri yang sama dan sebagian besar penderita adalah karyawan yang waktunya banyak dihabiskan di kantor sebagai operator komputer.

\section{Metode}

Subjek penelitian adalah operator komputer di kecamatan Bandar Jaya kabupaten Lampung Tengah yang memenuhi kriteria inklusi, yaitu usia 30-55 tahun, masa kerja $\geq 2$ tahun, dan tidak menderita penyakit yang menyebabkan keluhan nyeri punggung (artritis/ankylosing spondylitis/ osteoporosis), serta indeks massa tubuh (IMT) lebih dari 25,0. Subjek yang memenuhi kriteria penelitian sebanyak 77 dari 120 operator komputer.

Penelitian potong silang dilakukan 1-30 April 2008. Data primer diperoleh dari hasil wawancara terstruktur dengan menggunakan kuesioner, pengamatan secara langsung, serta pengukuran antropometri dengan menimbang berat dan mengukur tinggibadan.

Posisi dan lama duduk merupakan variabel bebas, sedangkan nyeri punggung merupakan variabel terikat. Posisi duduk didefinisikan sebagai posisi dengan tangan sejajar lengan bawah, kepala tidak menunduk, pandangan sejajar dengan monitor, punggung tertopang, bahu santai, dan kaki terletak pada bantalan. Hasil pengukuran dikategorikan dalam skala nominal menjadi 0 untuk jawaban tidak (posisi duduk tidak baik), yaitu bila persyaratan posisi duduk yang baik tidak terpenuhi. Angka 1 untuk jawaban ya (posisi duduk baik), bila persyaratan posisi duduk yang baik terpenuhi semua. Lama duduk didefinisikan sebagai waktu bekerja dengan komputer selama satu hari. ${ }^{9}$ Hasil 
Tabel 1 Hubungan Posisi Duduk dengan Nyeri Punggung

\begin{tabular}{|c|c|c|c|c|}
\hline \multirow{2}{*}{ Posisi Duduk } & \multicolumn{2}{|c|}{ Nyeri Punggung } & \multirow{2}{*}{ Total } & \multirow{2}{*}{ Uji Statistik } \\
\hline & Ya & Tidak & & \\
\hline Tidak baik & $11(91,7 \%)$ & $1 \quad(8,3 \%)$ & $12(100 \%)$ & $\mathrm{p}=0,011$ \\
\hline Baik & $27(41,5 \%)$ & $38(58,5 \%)$ & $65(100 \%)$ & $\operatorname{Exp}(B)=15,481$ \\
\hline
\end{tabular}

Tabel 2 Hubungan Lama Duduk dengan Nyeri Punggung

\begin{tabular}{|c|c|c|c|c|}
\hline \multirow{2}{*}{ Lama Duduk } & \multicolumn{2}{|c|}{ Nyeri Punggung } & \multirow[b]{2}{*}{ Total } & \multirow{2}{*}{ Uji Statistik } \\
\hline & Ya & Tidak & & \\
\hline Lama & $37(58,7 \%)$ & $26(41,3 \%)$ & $63(100 \%)$ & $\mathrm{p}=0,006$ \\
\hline Tidak Lama & $1(7,1 \%)$ & $13(92,9 \%)$ & $14(100 \%)$ & $\operatorname{Exp}(B)=18,497$ \\
\hline
\end{tabular}

Tabel 3 Hubungan Posisi dan Lama Duduk dengan Nyeri Punggung

\begin{tabular}{lccccc}
\hline & B & S.E. & Wald & p & $\operatorname{Exp(B)}$ \\
\hline Posisi Duduk & 3,063 & 1,285 & 5,681 & 0,017 & 21,400 \\
Lama Duduk & 3,203 & 1,244 & 6,633 & 0,010 & 24,607 \\
\hline
\end{tabular}

pengukuran lama duduk dikategorikan menjadi 0 (skala nominal) untuk jawaban tidak (duduk dalam waktu yang tidak lama), apabila skor jawaban kuesioner lebih rendah dari nilai median; 1 untuk jawaban ya (duduk lama), apabila skor jawaban kuesioner $\geq$ nilai median jawaban. Nyeri punggung didefinisikan sebagai rasa tidak nyaman sekitar punggung yang dirasakan saat bekerja dengan komputer.

Analisis statistik yang digunakan adalah regresi logistik bivariat dan multivariat untuk mengetahui pengaruh variabel bebas terhadap variabel terikat.

\section{Hasil}

Sebanyak 65 dari 77 responden $(84,4 \%)$ duduk dengan posisi baik saat bekerja dengan komputer, sedangkan 12 responden $(15,6 \%)$ duduk dengan posisi tidak baik. Keluhan nyeri punggung terjadi sebanyak $41,5 \%$ pada posisi duduk baik dan 91,7\% pada posisi duduk tidak baik.

Hubungan posisi duduk dengan nyeri punggung tertera pada Tabel 1. Berdasarkan uji regresi logistik bivariat diperoleh nilai $\mathrm{p}=0,011$ dan $\operatorname{Exp}(\mathrm{B})$ sebesar 15,481 yang berarti responden yang duduk dengan posisi tidak baik mempunyai risiko 15,481 kali lebih besar terjadinya nyeri punggung dibanding responden yang duduk dengan posisi baik. Diperoleh nilai $\mathrm{R}^{2}$ sebesar 0,187 yang berarti $18,7 \%$ nyeri punggung dapat dihubungkan dengan posisi duduk.
Hubungan antara lama duduk dan nyeri punggung tertera pada Tabel 2. Sebanyak 63 responden $(81,8 \%)$ bekerja memakai komputer dalam waktu lama ( $>4$ jam), 37 orang $(58,7 \%)$ mengalami nyeri punggung, sedangkan yang tidak duduk lama hanya satu orang $(7,1 \%)$. Berdasarkan uji regresi logistik diperoleh nilai $\mathrm{p}=0,006$ dan nilai $\operatorname{Exp}(\mathrm{B})$ sebesar 18,497 yang berarti duduk lama mempunyai risiko 18,497 kali lebih besar untuk nyeri punggung dibandingkan dengan responden yang duduk tidak lama. Diperoleh nilai $\mathrm{R}^{2}$ sebesar 0,223 , berarti $22,3 \%$ kejadian nyeri punggung berhubungan dengan lama duduk.

Tabel 3 menunjukkan hubungan posisi dan lama duduk dengan nyeri punggung. Berdasarkan uji multivariat regresi logistik diperoleh hasil bahwa posisi dan lama duduk secara bersamasama mempengaruhi nyeri punggung $(p=0,017$ dan 0,010$)$. Hasil analisis juga memperoleh nilai $\operatorname{Exp(B)~sebesar~21,400~dan~24,607~yang~berarti~}$ bahwa posisi duduk tidak baik dan duduk lama mempunyai risiko 21,400 dan 24,607 kali lebih besar untuk terjadinya nyeri punggung. Diperoleh nilai $R^{2}$ sebesar 0,344 yang berarti $34,4 \%$ kejadian nyeri punggung dapat dihubungkan dengan posisi dan lama duduk.

\section{Pembahasan}

Sebagian besar responden bekerja dengan posisi duduk yang baik $(84,4 \%)$. Hasil penelitian ini 
berbeda dengan yang dilakukan oleh Idyan, menyatakan bahwa kebanyakan responden dalam penelitiannya duduk dalam posisi yang tidak baik disebabkan tempat duduk yang tidak ergonomis. Berdasarkan hasil wawancara diketahui bahwa posisi duduk sangat ditentukan oleh kemudahan menjalankan pekerjaan mereka sebagai operator komputer, yaitu kemudahan untuk menjangkau peralatan komputer seperti mouse dan keyboard. Selain itu posisi duduk juga ditentukan oleh kursi yang digunakan. Hasil pengamatan mendapatkan bahwa perangkat komputer telah ditempatkan pada posisi yang mudah dijangkau, selain itu sebagian besar kursi yang digunakan telah didisain mengikuti bentuk tubuh atau menyangga punggung dengan baik, serta dapat diatur tinggi rendahnya sesuai postur tubuh. Pada pekerjaan yang dilakukan dengan posisi duduk, sebaiknya tempat duduk yang dipakai harus memungkinkan melakukan variasi perubahan posisi.

Analisis univariat variabel memperlihatkan bahwa $38(49,4 \%)$ responden mengalami nyeri punggung. Hasil penelitian ini berbeda dengan penelitian yang dilakukan oleh Idyan ${ }^{11}$ yang menyatakan bahwa $88,5 \%$ responden yang diteliti mengalami nyeri punggung. Sebagian besar responden yang mengalami nyeri punggung menyatakan kekakuan dan nyeri otot punggung. Hal tersebut sesuai dengan gejala nyeri punggung yang sering dirasakan penderita, yaitu kaku otot dan nyeri punggung yang menetap. ${ }^{1}$

Pada analisis bivariat posisi duduk dan nyeri punggung, hasil penelitian menunjukkan ada pengaruh posisi duduk terhadap nyeri punggung $(\mathrm{p}=0,011)$ dan duduk dengan posisi tidak baik mempunyai risiko 15,481 kali lebih besar untuk terjadinya nyeri punggung. Hasil penelitian ini sesuai dengan yang dilakukan oleh Mataram dkk. ${ }^{12}$ yang mendapatkan hubungan bermakna antara posisi duduk dan keluhan nyeri punggung. Penelitian yang dilakukan Adiatmika dkk. ${ }^{13}$ juga sesuai dengan penelitian ini, karena dinyatakan terdapat penurunan keluhan muskuloskeletal dan kelelahan akibat perbaikan kondisi kerja dengan pendekatan model ergonomi total. Duduk dalam posisi baik sangat penting sebab jaringan pada tulang belakang terhubung dengan ligamen dapat memicu rasa sakit jika posisi tidak tepat dan dapat berkembang menjadi penyakit kronik apabila dibiarkan. Duduk di atas kursi dengan sandaran yang baik dapat memberikan posisi yang nyaman pada tulang belakang, mengurangi dan mencegah nyeri punggung, serta lebih baik daripada mengobati penyakit yang sudah kronik akibat posisi tubuh salah dalam waktu lama. ${ }^{13}$ Kondisi ergonomi kerja yang baik menurunkan risiko kesehatan seperti nyeri punggung. ${ }^{1}$

Analisis univariat variabel lama duduk menunjukkan sebagian besar responden $(81,8 \%)$ duduk dalam waktu lama ( $>4$ jam). Sebanyak $28,6 \%$ responden bekerja di instansi pemerintah dan $71,4 \%$ di instansi swasta. Responden yang bekerja di instansi pemerintah, dalam satu hari rata-rata bekerja mempergunakan komputer selama 4-5 jam, sedangkan di instansi swasta ratarata 7-8 jam. Diketahui pula bahwa $45,4 \%$ responden beristirahat setiap 30-60 menit bekerja, sedangkan 54,6\% lebih dari 1 jam. Duduk dengan posisi yang sama $\geq 30$ menit dapat menyebabkan nyeri punggung, oleh karena itu setiap 30-60 menit bekerja diperlukan istirahat. ${ }^{2,6}$

Pada analisis bivariat lama duduk dan nyeri punggung, ternyata lama duduk berpengaruh terhadap nyeri punggung $(\mathrm{p}=0,006)$, dan duduk lama mempunyai risiko 18, 497 kali lebih besar untuk terjadinya nyeri punggung. Hasil penelitian ini sesuai dengan penelitian Mataram dkk. ${ }^{12}$ yang mendapatkan hubungan bermakna lama duduk dengan nyeri punggung. Untuk mempertahankan faal kerja normal, diperlukan pengaturan waktu kerja yang pada umumnya berkisar 6-8 jam, lebih dari itu menimbulkan kelelahan otot. ${ }^{14}$ UndangUndang Ketenagakerjaan juga mengatur waktu kerja yang menyatakan jumlah jam kerja 1 hari adalah 7-8 jam, dan dalam 1 minggu bekerja 40 jam. ${ }^{15}$

Tabel 5 memperlihatkan gabungan posisi dan lama duduk berpengaruh lebih besar terhadap nyeri punggung $(\mathrm{p}=0,017$ dan $\mathrm{p}=0,010)$ dibanding pengaruh masing-masing variabel. Responden yang duduk dengan posisi tidak baik dan duduk lama mempunyai risiko nyeri punggung 21,400 dan 24,607 kali dibanding 15,481 kali pada posisi duduk tidak baik saja dan 18,497 kali pada duduk lama. Hasil $\mathrm{R}^{2}=0,344$ menunjukkan gabungan posisi dan lama duduk lebih kuat hubungannya terhadap nyeri punggung dibandingkan dengan posisi $\operatorname{duduk}\left(\mathrm{R}^{2}=0,187\right)$ atau lama duduk $\left(\mathrm{R}^{2}=0,223\right)$.

Dapat disimpulkan bahwa posisi serta lama duduk masing-masing akan berpengaruh terhadap nyeri punggung dan merupakan faktor risiko. Gabungan keduanya meningkatkan pengaruh dan risiko terhadap nyeri punggung. Disarankan 
melakukan peregangan otot setelah 30-60 menit bekerja untuk mengurangi nyeri punggung.

\section{Daftar Pustaka}

1. Bull E, Archad G. Nyeri punggung. Jakarta: Erlangga; 2007.

2. Occupation safety $\&$ health administration. Work Process. 2008 (diunduh 16 Mei 2008). Tersedia dari: URL: http://www.osha.gov/SLTC/etools/ computerworkstations/components chair.

3. Abeysekera J. Ergonomics and industrially developing countries. J Ergonomi Indonesia. 2002;3 (1):24-6.

4. Purnawati S. Keluhan muskuloskeletal karyawan pada CV. DS di desa Mas. J Ergonomi Indonesia. 2002;3(1):31-7.

5. Wardhana, Supriyono, Harsono. Aspek keselamatan kerja pada pemakaian komputer. 1997 (diunduh 4 Maret 2008). Tersedia dari: URL: http:// www.elektroonline.co.id.

6. Tirtayasa K. Kapasitas kerja (work capacity) aspek sistem neuromuskular. J Ergonomi Indonesia. 2003;4(1):44-7.

7. Rumah Sakit Umum Daerah Demang Sepulau Raya. Data rekam medis tahun 2008. Lampung Tengah:2008.
8. Occupation safety $\&$ health administration. Chairs and desks. 2008 (diunduh 16 Mei 2008). Tersedia dari: URL: http://www.osha.gov/-SLTC/etools/ computerworkstations/components_chair.

9. Tarwaka, Bakri SHA, Sudiajeng L. Ergonomi untuk keselamatan, kesehatan kerja dan produktivitas. Surakarta: Uniba Press; 2004.

10. Idyan Z. Hubungan lama duduk saat perkuliahan dengan keluhan "low back pain" . 2008 (diunduh 16 Mei 2008). Tersedia dari: URL: http:// www. inna-ppni.or.id/index.php?-name $=$ News \&file $=$ article\&sid $=130$.

11. Mataram, Partha, Wijaya. Kelelahan pada pengetikan dengan menggunakan komputer. J Ergonomi Indonesia. 2000;1(1):51-8.

12. Adiatmika, Manuaba, Adiputra, Sutjana. Perbaikan kondisi kerja dengan pendekatan ergonomi total menurunkan keluhan muskuloskeletal dan kelelahan. J Ergonomi Indonesia. 2007;8(1):45-7.

13. National Institute of Neurological Disorder and Stroke. Low back pain fact sheet. 2009 (diunduh 10 Mei 2009). Tersedia dari: URL: http:// www.ninds.nih.gov/disorders/backpain/-detail_ backpain.htm?css=print.

14. Suma'mur. Ergonomi untuk produktivitas kerja. Jakarta: CV Haji Masagung;1998.

15. Undang-Undang Ketenagakerjaan. Waktu kerja, pasal 77, ayat 2. Jakarta: Sinar Grafika; 2007. 